\title{
Isis and the Archaeological Heritage
}

\author{
Andrea Beccaro* \\ Research Fellow at Department of Humanistic Studies, University of Eastern Piedmont, Italy
}

Submission: May 25, 2018; Published: June 25, 2018

*Corresponding author: Andrea Beccaro, Research Fellow at Department of Humanistic Studies, University of Eastern Piedmont, Vercelli, Email: Andrea.Beccaro@Uniupo.It

Keywords: Archaeological; Heritage; Political; Livestock; Kidnapping; Hybrid Warfare; Controlled; Expanding; Remaining; Far Abroad; Capital Assets; Gold; Un-Islamic Heritage; Twitter; Facebook; Youtube; Telegram

\section{Commentary}

ISIS (The Islamic State Of Iraq And Syria) Has Become a Key Political and Military Actor in the Middle East And In North Africa [1]. However The Group's Momentum has slowed over the Past Years, and it Has Lost its Hold in Syria and in Iraq. In Spite of this, since 2013 It has Conquered, Controlled, and Ruled Vast Areas of Syria and Iraq, And Cities and Villages In Libya. It operates in Sinai and Has Carried out Attacks around Europe. Most Important the Group has Been Forced out of Key Cities and Areas, Such as Mosul, Palmira, and Raqqa. These Defeats Were Crucial for the Militias Both Because Mosul and Raqqa Represented Strong Propaganda Tools Linked to the Strategic Idea of "Remaining and Expanding" and because those Areas were of Strategic importance due to their Economic Relevance.

ISIS Economy was based on Several Revenues Such as Kidnapping, Taxation of Resident, Criminal Activities, Zakat (That is extracted from Annual Savings or Capital Assets, Gold, Livestock), and the Imposition of Annual Taxes on Non-Muslims Living in its Territories, Especially Christians, Confiscation of the Properties of Displaced or Wanted Individuals, and Donations from Foreign Donors. However the Most Important Were: Selling of Oil and Artefacts.

According to Weiss \& Hassan [2] Oil was a Major Revenue Generator for ISIS at Least Until the Coalition Air Strikes Began (August 2014). It Is Very Difficult to Have Reliable Data, But it is Believed that ISIS Earned Millions of Dollars a Month (Approximately \$1 To 2 Million a Day) from Oil in Syria Province of Deir Er Zor and Iraq. Although The Revenue Dropped Significantly Due to the American Air Strikes that Targeted Before ISIS In Iraq and then the Group in its Strongholds in Syria (September 2014), Oil Smuggling To Neighbouring Countries Such as Turkey and Jordan has Continued Making Significant Revenue For ISIS. Nevertheless for the Purposes of this Paper ISIS' Trafficking of Looted Antiquities is More Important. The Trade in Items Stolen from Iraq and Syria's Historical Sites (Mainly Mosul Museum and its Archaeological Sites and Palmira) Generated Revenue around $\$ 100$ Million. But how it was Possible?

First of all we need to understand what ISIS was/is: it is a Propaganda Machine. Not only ISIS has Been Able to Produce Hundreds of Propaganda Videos, but it was Able to Spread Them Worldwide Using Social Media Such As Twitter, Face book, YouTube, Telegram and so on. In 2015 the Group Started to Broadcast A Series of Video in Which Several Militiamen were Destroying Cases in the Mosul Museum, Statues, Sculptures And Buildings in Palmira. These Videos Should be Understood in two Different Way. First, They Were Propaganda Tool Aiming at Publicizing to Possible Future Member the Idea that ISIS had a Very Strict Interpretation of Quran and Sharia and Consequently it was a True salafist Movement That Was Building A True And Pure Islamic State Destroying the Old and Un-Islamic Heritage. Yet, the True Message of Those Videos Was Another, I.E. Showing to Western Collectors That ISIS Had Available Several Artefacts of Different Kind that Could Be Sell And Bought. As a Consequence not only ISIS Plundered Museums And Archaeological Sites, But It Also Gave Locals Special Licenses to Dig for Antiquities In order to Increase this Market.

Unfortunately it is Very Difficult to Have Information About this Traffic but Sometimes on National and International Newspaper Some News Emerges. For Example, on 21 $1^{\text {st }}$ May 2018 Italian Carabinieri have Seized a Container in Salerno [3] in Which they Found Several Artefacts Among Which an Egyptian Gold Mask, A Sarcophagus and the "Boat of the Dead", Which Represents the Most Valuable Piece in Terms of Value. The Artistic Heritage Came from Alexandria, Egypt, and Travelled Within a Container on a Diplomatic Load. However, this is Just the Last Example of the ISIS Trade of Archaeological Artefacts. For Instance, on 28th March 2018 Spanish Police Arrested in Barcelona two Men for their Participation in The Crimes of Financing Terrorism throughout the Smuggling of Pieces of 
Art Looted by Groups Affiliated with ISIS from Sites in Libya. Police Recovered Artworks Including Sculptures, Mosaics and Sarcophagi and traced their origin to the apollonia and Cyrene Archaeological Sites in Northern Libya [4]. On $3^{\text {rd }}$ July 2015 Mark altaweel from the UCL Institute of Archaeology Uncovered Objects (Pieces of Early Glass; a Tiny Statue; Some Fragments Of Bone Inlay) that are "Very Likely to be Coming from Conflict Regions" in Iraq And Syria [5]. Around the Same Time UNESCO was concerned that the Looting in ISIS Controlled areas was Taking Place on Industrial Scale [6].

The Recent Italian Seizing and these other Examples Demonstrate at Least Three Things Related to ISIS And one More to Terrorism as a Political Phenomenon. First, ISIS is Still Alive. it Has Lost Most of its Territories In The Middle East and North Africa, But its Ideology, its Cells, and its Members are Still at Large And Continue to Represent a Major and Serious Threat for the Security in the Entire Mediterranean Area. Second, ISIS has been able to expand not only in Iraq and Syria, Where it had its Core Territories, But Also Elsewhere. To Better Understand the Territorial Organization of ISIS Gambhir described it as a Three Rings Structure: The "Interior" Ring, The Middle East, where ISIS focused its Main Effort; The "Near Abroad" Ring is Stretching from Morocco to Pakistan; the "Far Abroad" Ring Encompasses the Wider World, and Cyberspace [7]. As a Consequence ISIS appears to be Extended All over the Mediterranean Region and to have Branches in Several States Such as Egypt, Libya, Syria, Iraq. Third, It Has Good and Close Connection with Some Local Politicians.

As For the Issue of Terrorism the Looting of Artefacts Demonstrates clearly that there is a Link between Two Phenomena, I.E. Terrorism and Criminality. Terrorist Organizations Use Criminal Activities to Fund and Support their operations as the Selling of oil and the Looting of Piece of Arts in The Case of ISIS Demonstrate. However This Link is Also Evident in the Theory of Terrorism. For Instance, one of The

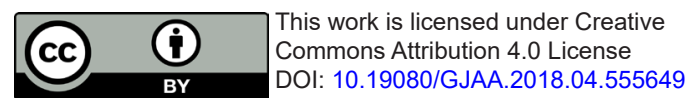

First Theorists of the Use of Terrorism, Michail Aleksandrovič Bakunin, Wrote that in Order to Win Terrorists Have to Join the Criminals. Another Author, Johann Most, Wrote that Robbery and Theft Are Integral Part of a Terrorist Campaign because it is Impossible to Fight a Revolution without Money [8]. In The Sixties the Brasilian Carlos Marighella Wrote The Minimanual of the Urban Guerrilla In Which He Pointed out the Importance of Urban Operations Because, Among other Things, Within Cities Terrorist Cells Can Find Banks and Other Economic Targets that Could Help Them to Fund their Operations [9]. Finally, The Link Between Criminal Activities And Terrorism Is Well Established by "Hybrid Warfare" Theory That Stresses The Merge Of Different Tactics And Phenomena in the XXI Century Warfare Creating A Kind of "New" Irregular War.

\section{References}

1. Lister R C (2015) The Islamic State: A Brief Introduction Brookings Institution Press, Washington; Cockburn P (2015) The Rise of Islamic State: ISIS and the New Sunni Revolution Verso, New York, USA.

2. Weiss M, Hassan H Isis: Inside the Army of Terror Regan Arts Books, New York, USA, p. 184.

3. The archaeological assets subtracted from the Isis in the "Tofano" barracks of Nocera Inferior (2018) Italy seizes smuggled Egypt artefacts, Europe.

4. Lorenzo D Agostino (2018) Two Spaniards arrested over smuggling of artefacts looted by ISIS.

5. https://www.theguardian.com/world/2015/jul/03/antiquitieslooted-by-isis-end-up-in-london-shops.

6. https://uk.reuters.com/article/uk-mideast-crisis-unesco/islamicstate-looting-syrian-iraqi-sites-on-industrial-scale-unescoidUKKCNOPC1OS20150702.

7. http://www.understandingwar.org/sites/default/files/ISIS $\% 20$ INTSUM_Final.pdf.

8. Laqueur W, Yonah A (1987) The Terrorism Reader. The Essential Source Book on Political Violence Both Past and Present Meridian Book New York, USA, pp. 101-102.

9. Marighella C (2002) Mini-Manual of the Urban Guerrilla Abraham Guillen Press, Montreal, Canada.

\section{Your next submission with Juniper Publishers will reach you the below assets}

- Quality Editorial service

- Swift Peer Review

- Reprints availability

- E-prints Service

- Manuscript Podcast for convenient understanding

- Global attainment for your research

- Manuscript accessibility in different formats

( Pdf, E-pub, Full Text, Audio)

- Unceasing customer service

Track the below URL for one-step submission

https://juniperpublishers.com/online-submission.php 